\title{
Geochemical characteristics of the Permian sedimentary rocks from Qiangtang Basin: Constraints for paleoenvironment and paleoclimate
}

\author{
Junjie $\mathrm{Hu}^{1,2}$, Qi $\mathrm{Li}^{2,3,{ }^{*}}$, Chunyan Song ${ }^{4}$, Shuangqing Wang ${ }^{5}$, and Bin Shen ${ }^{5}$ \\ ${ }^{1}$ Institute of Geomechanics, Chinese Academy of Geological Sciences, Beijing, China \\ ${ }^{2}$ The Key Laboratory of Unconventional Petroleum Geology, CGS, Beijing, China \\ ${ }^{3}$ School of Ocean Sciences, China University of Geosciences, Beijing, China \\ ${ }^{4}$ Chengdu Institute of Geology and Mineral Resources, Chengdu, China \\ ${ }^{5}$ National Research Center for Geoanalysis, Beijing, China
}

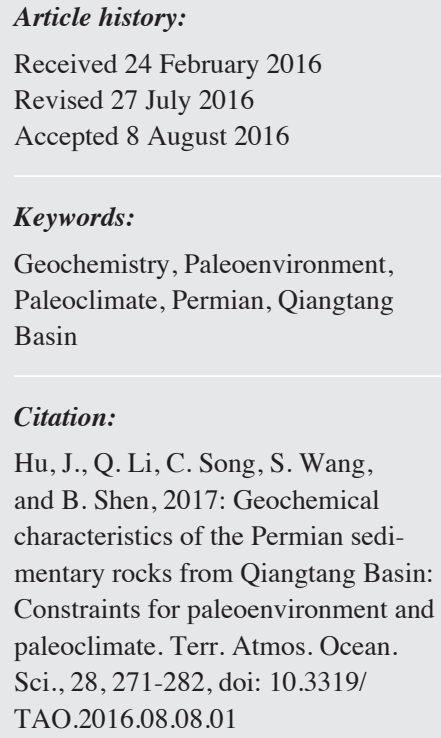

\begin{abstract}
Qiangtang Basin is expected to become important strategic petroleum exploitation area in China. However, little research has been done on the Permian strata in this area. This paper presents Lower Permian Zhanjin Formation geochemical data from the Jiaomuri area, reconstructing the paleo-depositional environment and providing information for further petroleum exploration. The geochemical characteristics of 19 samples were investigated. These geochemical samples show a developed mud flat characteristic with light rich clay content. The geological data were used to constrain the paleoredox environment, which proved that these sediments were deposited mainly beneath a slightly oxic water column with relatively low paleoproductivity as evidenced by the $\mathrm{P} / \mathrm{Ti}$ (mean of 0.07 ) and $\mathrm{Ba} / \mathrm{Al}$ (mean of 20.5). Palaeoclimate indexes such as the $\mathrm{C}$-value (0.24-1.75) and $\mathrm{Sr} / \mathrm{Cu}(1.28-11.58)$ reveal a humid climatic condition during Zhanjin Formation sediment deposition. The $\omega(\mathrm{La})_{\mathrm{N}} / \omega(\mathrm{Yb})_{\mathrm{N}}$ ratio values indicate a fast sedimentary rate during the deposition period.
\end{abstract}

\section{INTRODUCTION}

The Qiangtang Basin is located in the northern part of the Qinghai-Tibet Plateau. This region covers the eastern section of the Tethys structural domain, which is known to be rich in oil and gas reserves (Ding et al. 2013). Tectonically, Qiangtang Basin is bounded by the Gangdise-Nyenchen Tanglha and Hox Xil-Bayankala plates (Fig. 1). The basin has complex structures whose tectonic framework can be described as "one uplift bounded by two depressions" (Hu et al.2015). Paleozoic- Mesozoic marine sedimentary strata occur extensively throughout the basin, preserving a complete Qinghai-Tibet Plateau sequence.

This large, onshore basin is the biggest residual petroleum-bearing basin on the Qinghai-Tibet Plateau and has been the subject of an important strategic petroleum

\footnotetext{
* Corresponding author

E-mail: liqi@cugb.edu.cn
}

exploitation area in China. In recent years a number of investigations including geological surveys, geochemical exploration, geophysical surveys, and laboratory analysis have been taken to evaluate the exploration potential of this region (Guo et al. 2008; He et al. 2012; Ding et al. 2013; Fu et al. 2013). Previous studies confirmed more than 200 oil/gas shows from Mesozoic formations (Fu et al. 2013) and obtained important paleoenvironment research results in the Triassic and Jurassic Qiangtang Basins (Wang et al. 2007; Feng et al. 2010; Song et al. 2013a, b). However, relative studies on Paleozoic sedimentary strata are still sparse. In 2012, cores from the Qiangzi 5 Well were successfully acquired in the Jiaomuri area. These core samples ascertained the existence of Permian hydrocarbon accumulation in the Qiangtang Basin uplift zone (Song et al. 2014). Using organic geochemical analysis Cao et al. (2015) suggested that the Lower Permian Zhanjin Formation 
source rock organic matter generally derived from marine low-grade aquatic organisms and thermally evolved into a mature stage. However, based on the significant differences in the organic geochemical parameters, Song et al. (2014) indicated that the oil hydrocarbons in dolomite may not be derived from its adjacent Zhanjin Formation silty mudstone. These cores also provide an excellent chance to understand the sedimentary condition during the Permian period in Qiangtang Basin, but have been barely discussed in the literature.

This study presents Low Permian sediment geochemical data from the Qiangzi 5 Well in the Qiangtang Basin central uplift. Based on the chemical analysis an attempt is made to reveal the hydrodynamic conditions, paleoclimate and redox conditions, with the aim at reconstructing the depositional environment and providing information for petroleum exploration in Qiangtang Basin.

\section{GEOLOGICAL SETTING AND SAMPLING}

The Jiaomuri area is situated at the center of the Qiangtang Basin central uplift zone (Fig. 1). The Longmu Co-Shuanghu suture runs across the northern study area, separating the study area strata into the Gondwana affiliated stratigraphic system of south Qiangtang Basin and the Yangtze affiliated stratigraphic system of north Qiangtang Basin (Jin 2002) (Fig. 1). Typical limestone, volcanic clastic rocks, siliceous rocks, and clastic sedimentary rock interfingers developed in this area (Zhai et al. 2004). Permian radiolarian siliceous rocks ( $\mathrm{Li}$ et al. 2007) indicate that the area was in a deep ocean/bathyal ocean environment. The Permian strata in the Qiangtang Basin are mainly exposed in the west to Shuanghu Special District (Zhang et al. 2013). The Low Permian Zhanjin Formation is generally distributed along the Jiaomuri-Zhisai area, whose strata profile show tufaceous sandstones/mudstones and basic volcanic rocks, locally intercalated with thin medium bedded micritic limestone and micrite. These rocks show some structural flysch facies characteristics feeding trace fossils and turbidite.

The samples were collected for the present study from fine-clastic sedimentary cores from the Qiangzi 5 Well. This well was drilled by the Chengdu Institute of Geology and Mineral Resources in the Jiaomuri area (Fig. 1), revealing $1001 \mathrm{~m}$ Lower Permian Zhanjin Formation and Middle Permian Longge Formation succession strata. The drilling cores show that, lithologically, the Zhanjin Formation consists of a dolomite section (867 - $1011 \mathrm{~m}$ interval of the well), volcanic breccia section $(698-867 \mathrm{~m})$, and fine-clastic sediments section (413 - 698 m, Fig. 2) bottomup. It is in conformable contact with the overlying Longge Formation micritic limestone. A total of 19 core samples were collected from the fine-clastic sediments section of the Zhanjin Formation. The samples are composed mainly of pelitic siltstone, silty mudstone and siltstone.

\section{METHODOLOGY}

Major and trace elements analyses were performed at the CNNC Beijing Research Institute of Uranium Geology laboratory, following the method of the Chinese National Standard DZ/T 0223-2001. Each sample was first smashed into small pieces and further separated into grain size less than 200 mesh using standardized dry sieving.

Major element concentrations were obtained using an X-ray fluorescence spectrometer (AB-104L, PW2404) for the subsequent analytical procedures: each powdered sample weighed $0.4 \mathrm{~g}$ and was equably stirred in Ni-pots with anhydrous $\mathrm{Li}_{2} \mathrm{~B}_{4} \mathrm{O}_{7}$ and dissolved with $\mathrm{NH}_{4} \mathrm{Br} 120 \mathrm{mg} \mathrm{mL}^{-1}$ liquid and suitable oxidant. The Ni-pots were then placed into the CLAISSIE sampling machine for liquation according to the procedure presented. Afterwards, the high-temperature melts were placed into molds and finally encased into plastic bags for preservation in desiccators. X-ray data were converted into concentrations using a computer program based on the matrix correction method. The accuracy was estimated to be $<2 \%$ for all major element oxides.

Trace element concentrations, including REEs, were measured using ELEMENT XR ICP-MS. The procedure is as follows. Powders were first weighed $(25 \mathrm{mg})$ and placed in a high pressure-resistant beaker with a 1:1 mixture of $\mathrm{HF}-\mathrm{HNO}_{3}$ and heated for $24 \mathrm{~h}$ at $80^{\circ} \mathrm{C}$ to be evaporated. Next, $1.5 \mathrm{~mL} \mathrm{HNO}_{3}, 1.5 \mathrm{~mL} \mathrm{HF}$, and $0.5 \mathrm{~mL} \mathrm{HClO}_{4}$ were added, respectively, after the solutions were evaporated to nearly dry. The beakers with solutions were then capped for digestion within a high-temperature oven at $180^{\circ} \mathrm{C}$ for at least $48 \mathrm{~h}$ until the samples were completely dissolved. The solutions were then diluted with $1 \% \mathrm{HNO}_{3}$ to $50 \mathrm{~mL}$ for determination. The accuracy was estimated to be $5 \%$ for all trace elements.

\section{RESULTS}

The major, trace and rare earth elements analyses and relative ratio results for 19 samples from the Qiangzi 5 Well are given in Tables 1,2, and 3. The average enrichment factors for the selected major and trace elements are shown in Figs. 3 and 4. Enrichment factors (EF) are used to describe the enrichment of a sedimentary rock element, defined using the following equation:

$\mathrm{EF}=\left(\mathrm{C}_{\text {sample }} / \mathrm{C}_{\mathrm{A} 1 \text { sample }}\right) /\left(\mathrm{C}_{\text {standard }} / \mathrm{C}_{\mathrm{A} 1 \text { standard }}\right)$

Average shale (AS; Wedepohl 1978, 1991) concentrations are utilized as the standard in this study.

\subsection{Major Element Characteristics}

Marine shales and mudstones can be regarded as the 
admixture of three end-member oxides: $\mathrm{SiO}_{2}$ (detrital quartz and/or biogenic silica), $\mathrm{Al}_{2} \mathrm{O}_{3}$ (clay fraction), and $\mathrm{CaO}$ (carbonate content) (Ross and Bustin 2009). The $\mathrm{Al}_{2} \mathrm{O}_{3}$ content in the samples range from $10.21-17.44$ wt.\% (averaging $14.34 \mathrm{wt} . \%$ ), which is close to the AS composition. The $\mathrm{SiO}_{2}$ contents are slightly lower than AS with the concentration varying from 32.92 - $62.02 \mathrm{wt} . \%$ (averaging 47.59 wt. \%). $\mathrm{CaO}$ concentrations show wide variation results between 0.75 and $17.20 \mathrm{wt} . \%$ (averaging $6.39 \mathrm{wt} . \%$ ). In the $\mathrm{Al}_{2} \mathrm{O}_{3} * 5-\mathrm{SiO}_{2}-\mathrm{CaO} * 2$ ternary plot (Brumsack 1989; Fig. 5), the sediments plot relatively close to the $\mathrm{Al}_{2} \mathrm{O}_{3}$ pole and the carbonate content shows an increasing trend. Compared with the AS composition the Zhanjin Formation sediments present a developed mud flat characteristic and light richer clay content. No notable $\mathrm{P}$ and $\mathrm{Mg}$ enrichments occur (Fig. 3). The Mn and Na concentrations show wide variations, while most samples show that the $\mathrm{Fe}$ and Ti contents are more enriched than the AS composition. The good correlation between $\mathrm{TiO}_{2}$ and $\mathrm{Al}_{2} \mathrm{O}_{3}(\mathrm{r}=0.72)$ suggests either the occurrence of $\mathrm{Ti}$ within clay lattices or that the detrital material came from a constant source with limited winnowing process effects (Ross and Bustin 2009).

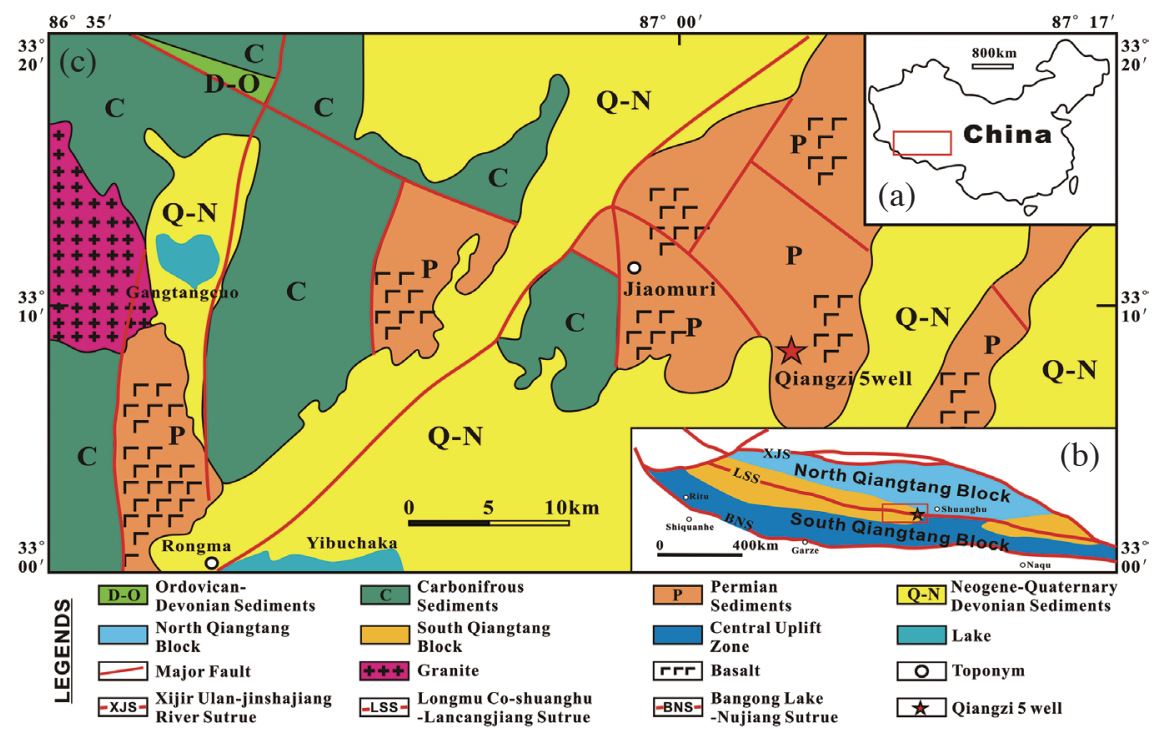

Fig. 1. Simplified geological map of Qiangzi 5 Well in the Jiaomuri area, central uplift zone, Qiangtang Basin, Tibet (Hu et al. 2015). (Color online only)

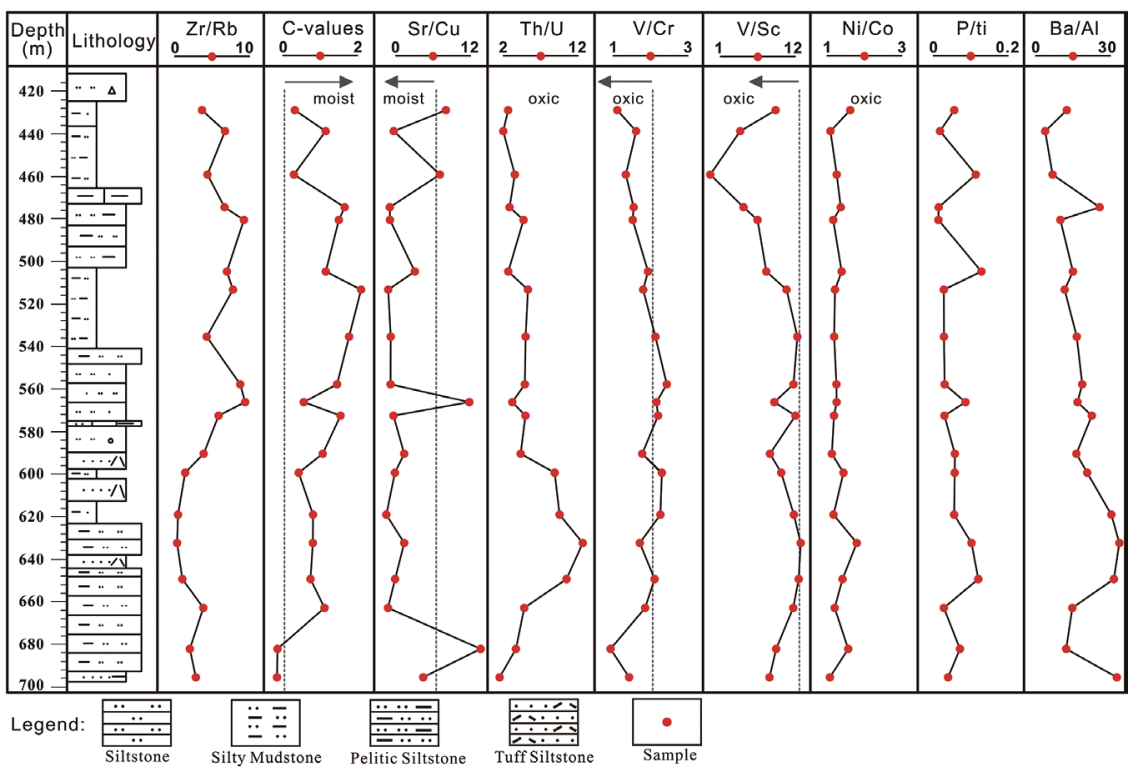

Fig. 2. Profiles of $\mathrm{Zr} / \mathrm{Rb}, \mathrm{C}$-values, $\mathrm{Sr} / \mathrm{Cu}, \mathrm{Th} / \mathrm{U}, \mathrm{V} / \mathrm{Cr}, \mathrm{V} / \mathrm{Sc}, \mathrm{Ni} / \mathrm{Co}, \mathrm{P} / \mathrm{Ti}$, and $\mathrm{Ba} / \mathrm{Al}$ in the $\mathrm{Zhanjin}$ Formation sedimentary rock samples from well Qiangzi 5 Well. (Color online only) 


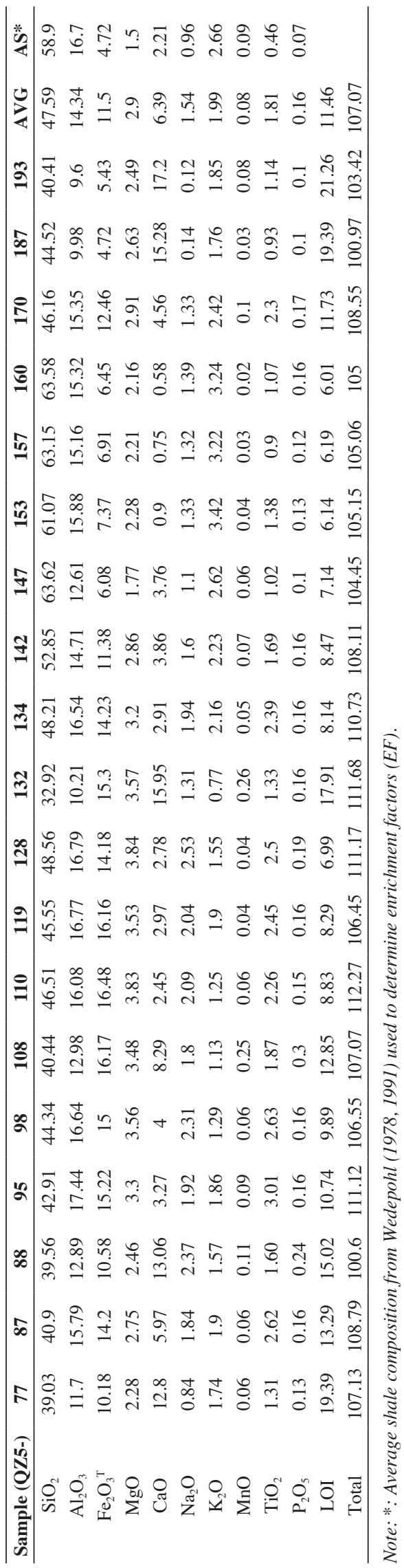

$$
\text { 을 }
$$




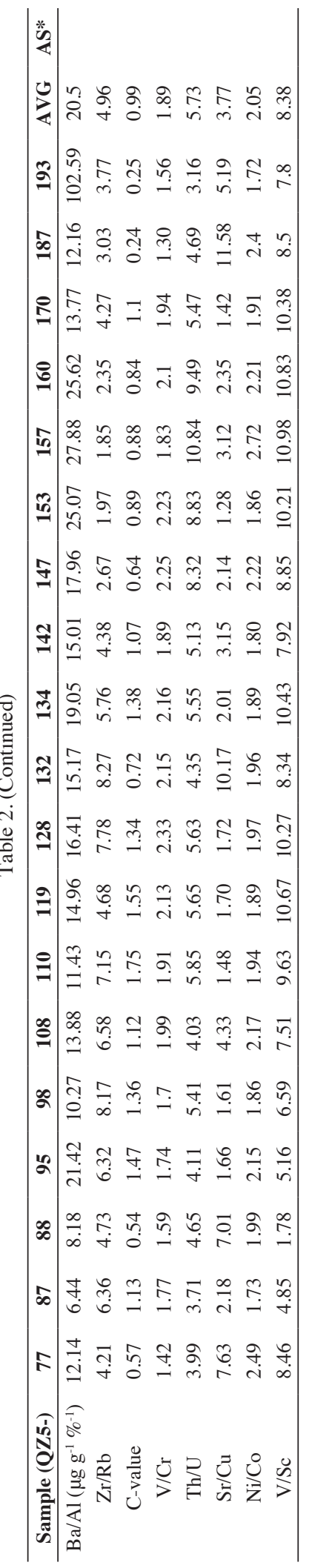

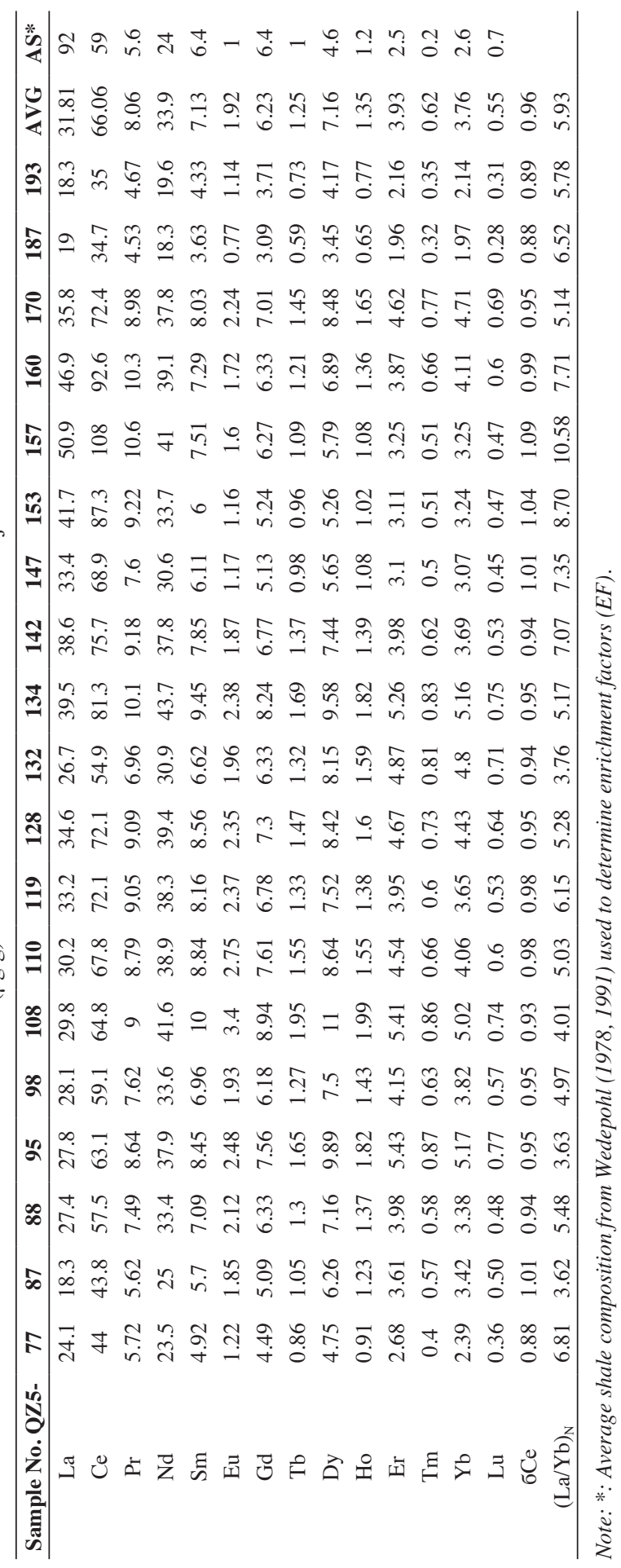




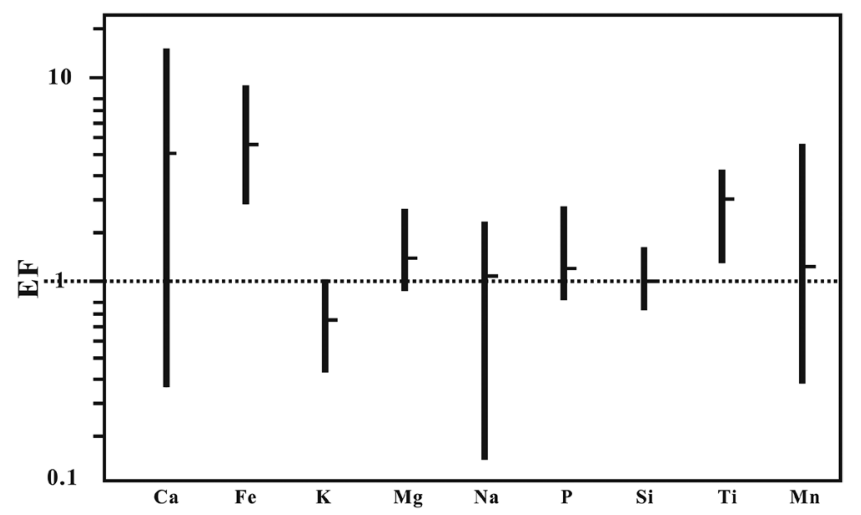

Fig. 3. Fluctuation and average values of major elements enrichment factor plot (EF), relative to average shales (AS), for the samples from the Qiangzi 5 Well (AS composition from Wedepohl 1978, 1991).

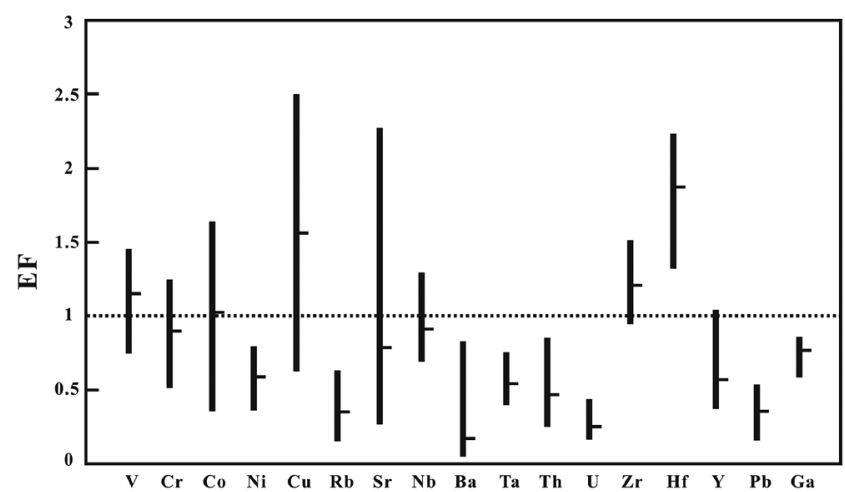

Fig. 4. Fluctuation and average values of trace elements enrichment factor plot (EF), relative to average shales (AS), for the samples from the Qiangzi 5 Well (AS composition from Wedepohl 1978, 1991).

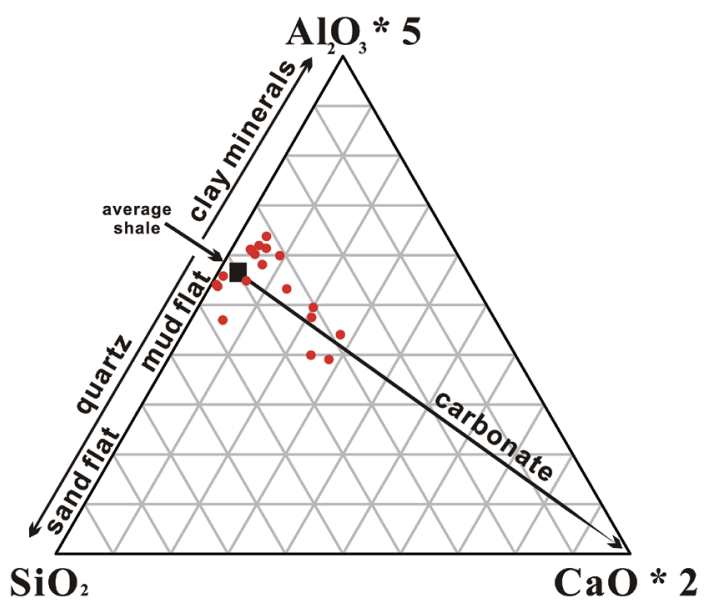

Fig. 5. Ternary plot $\mathrm{Al}_{2} \mathrm{O}_{3} * 5-\mathrm{SiO}_{2}-\mathrm{CaO} * 2$ (Brumsack 1989) representing the major components of the samples from the Qiangzi 5 Well. (Color online only)

\subsection{Trace Element Characteristics}

On average, the most abundant trace elements in the early Permian sediment samples are $\mathrm{V}$ (average $248.32 \mu \mathrm{g} \mathrm{g}^{-1}$ ), $\mathrm{Cr}$ (average $131.82 \mu \mathrm{g} \mathrm{g}^{-1}$ ), $\mathrm{Cu}$ (average $116.91 \mu \mathrm{g} \mathrm{g}^{-1}$ ), Zn (average $120.63 \mu \mathrm{g} \mathrm{g}^{-1}$ ), Sr (average $350.53 \mu \mathrm{g} \mathrm{g}^{-1}$ ), $\mathrm{Zr}$ (average $318.79 \mu \mathrm{g} \mathrm{g}^{-1}$ ), and Ba (average $145.95 \mu \mathrm{g} \mathrm{g}^{-1}$ ). All the other elements occur in amounts smaller than $100 \mu \mathrm{g} \mathrm{g}^{-1}$. In general, the trace element concentrations vary over a wide range (Table 2). According to the $\mathrm{EF}$ values, elements $\mathrm{V}(\mathrm{EF}=1.16), \mathrm{Cu}(\mathrm{EF}=1.56), \mathrm{Hf}$ $(\mathrm{EF}=1.88), \mathrm{Zr}(\mathrm{EF}=1.22), \mathrm{Sc}(\mathrm{EF}=1.51)$, and $\mathrm{Co}(\mathrm{EF}=$ 1.05 ) are slightly enriched. In contrast, $\mathrm{Rb}, \mathrm{Ba}, \mathrm{Th}, \mathrm{Y}, \mathrm{U}$, and Ta have an EF less than 0.6 and are therefore considered to be depleted.

The distributions of high field strength elements are controlled primarily by the alumino-silicate fraction (Ross and Bustin 2009). The immobile element concentrations for $\mathrm{Zr}$, Hf, and $\mathrm{Ga}$ in the samples have good correlations with $\mathrm{Al}_{2} \mathrm{O}_{3}$ ( $\mathrm{r}=0.83,0.87$, and 0.95 , respectively). Therefore, the enrichment of those elements may suggest the impact of continental detritus during the depositional period (Plank and Langmuir 1998). Nb-Ta and $\mathrm{Hf}-\mathrm{Zr}$ can be regarded as element pairs, essentially analogous to each other as they are not fractionated during most geological processes (Plank and Langmuir 1998). Due to the low mobility, $\mathrm{Nb}$ and $\mathrm{Hf}$ enrichment are excellent indicators of detrital input. In the Zhangjin Formation samples, $\mathrm{Nb}$ and $\mathrm{Hf}$ are slightly enriched, which probably indicates that these elements are transported through structural bonding or adhesion to clay minerals (Taylor and McClennan 1985). The Sr concentration ranges from $140-785 \mu \mathrm{g} \mathrm{g}^{-1}$ and exhibits a strong positive correlation with the $\mathrm{CaO}$ content in the samples $(\mathrm{r}=$ 0.80 ), probably due to their occurrence in multiple mineral phases and often affected by the carbonate content (Nesbitt and Young 1982; Wei et al. 2004).

\subsection{Rare Earth Element Characteristics}

The total rare earth element content ( $\sum$ REE) of Zhanjin sediments range from $120.29-241.32 \mu \mathrm{g} \mathrm{g}^{-1}$ with an average of $173.37 \mu \mathrm{g} \mathrm{g}^{-1}$. The average value of those samples is slightly higher than that of North American Shale Composition (NASC $=167.41 \mu \mathrm{g} \mathrm{g}^{-1}$; Haskin et al. 1968) and lower than that of Post-Archean Australian Average Shale (PAAS $=183.03 \mu \mathrm{g} \mathrm{g}^{-1}$; Taylor and McClennan 1985) and Average Shale (AS $=207.2 \mu \mathrm{g} \mathrm{g}^{-1}$; Wedepohl 1978, 1991). The light rare earth element ( $\Sigma$ LREE) concentrations are obviously higher than those of heavy rare earth elements ( $\Sigma$ HREE) with the LREE/HREE ratios varying from 4.42 - 10.12.

\section{APPLICATION FOR PALEODEPOSITIONAL ENVIRONMENT}




\subsection{Hydrodynamic Condition}

Hydrodynamics are the integrative effects of water depth, wave base and current velocity. The preservative quantity of organic matter in sediments generally increases with decreasing hydro energy (Hunt 1979). Zr is usually enriched in coarse-grained sediments in the form of zircon, but depleted in fine-grained sediments. $\mathrm{Rb}$ is deposited mainly in low hydro energy environments and gathered in finegrained minerals such as clay minerals and mica. Hence, the $\mathrm{Zr} / \mathrm{Rb}$ ratio can quantitatively reflect hydrodynamic changes as a proxy indication: a high $\mathrm{Zr} / \mathrm{Rb}$ value usually suggests a high-hydro energy environment and vice versa (Tenger et al. 2006). As shown in Table 2, the $\mathrm{Zr} / \mathrm{Rb}$ values of Zhanjin Formation sediments range from 1.85 - 8.27 (averaging = 3.77). In Fig. 2, the $\mathrm{Zr} / \mathrm{Rb}$ value is increasing bottom-up, roughly indicating that the hydro energy increased over time within the Zhanjin Formation sedimentation.

\subsection{Palaeoclimate Significance}

Palaeoclimate information is an important part of palaeoenvironment reconstruction. The distribution, composition and relative concentrations of some trace elements in sedimentary rock may reveal the palaeoclimatic variations. It has been generally accepted (Cao et al. 2012) that Fe, Mn, $\mathrm{Cr}, \mathrm{V}, \mathrm{Ni}$, and $\mathrm{Co}$ are relatively enriched under moist conditions. In contrast, the strengthening of water alkalinity due to evaporation under arid conditions prompts saline minerals to precipitate; thereby $\mathrm{Ca}, \mathrm{Mg}, \mathrm{K}, \mathrm{Na}, \mathrm{Sr}$, and $\mathrm{Ba}$ are concentrated. For example, Zhao et al. (2007) applied the C-value as a proxy for climate changes to study the Permian palaeoclimate of northwest Junggar Basin. The C-value has been successfully used in palaeoenvironment condition reconstruction in the Qiangtang Basin and adjacent areas in Tibet (Fu et al. 2016; Wang et al. 2017). The C-value is calculated as:

$$
\mathrm{C}-\text { value }=\frac{\sum(\mathrm{Fe}+\mathrm{Mn}+\mathrm{Cr}+\mathrm{Ni}+\mathrm{V}+\mathrm{Co})}{\sum(\mathrm{Ca}+\mathrm{Mg}+\mathrm{Sr}+\mathrm{Ba}+\mathrm{K}+\mathrm{Na})}
$$

As shown in Fig. 6, the C-values for the Zhanjin Formation sediments range from $0.24-1.75$ (average $=0.99$ ), pointing out a predominantly moist paleoclimate. Furthermore, the $\mathrm{C}$-values show a clear upward increase, suggesting the climate was becoming much moister during the Zhanjin Formation depositional period.

The $\mathrm{Sr} / \mathrm{Cu}$ ratio index has also been used for palaeoclimatic investigations (Meng et al. 2012; Jia et al. 2013). Generally, high $\mathrm{Sr} / \mathrm{Cu}$ ratios reflect a hot arid climate, while low $\mathrm{Sr} / \mathrm{Cu}$ ratios indicate a warm humid climate (Jia et al. 2013). Lerman (1978) proposed that $\mathrm{Sr} / \mathrm{Cu}$ ratios between 1.3 and 5.0 suggest a warm humid climate, whereas a ratio greater than 5.0 points to a hot arid climate. The $\mathrm{Sr} / \mathrm{Cu}$ ratios of the early Permian Zhanjin Formation samples from the Qiangtang Basin range from 1.28 - 11.58, and the values of most samples are lower than 5, with an average of 3.77. This data distribution is consistent with the C-value (Fig. 2), also supporting a humid to semi-humid climatic condition.

\subsection{Palaeoredox Condition}

Sediment formation redox conditions were determined by analyzing several geochemical indicators. Previous studies demonstrated that the content of some redox-sensitive elements, such as $\mathrm{Cr}, \mathrm{V}$, Th, Mn, Ni, Co, Mo, and U, in marine sediments are generally controlled by the redox condition and therefore considered as reliable redox tracers in the fields of oceanography and environmental research (Yarincik et al. 2000). In oxic environments, $\mathrm{Mo}$ is present as stable $\mathrm{MoO}_{4}{ }^{2-}$. Conversely, in anoxic environments, $\mathrm{S}^{2-}$ can replace $\mathrm{O}^{2-}$ in $\mathrm{MoO}_{4}{ }^{2-}$ and become enriched in the sediments (Crusius et al. 1996; Algeo and Maynard 2004; Luo et al. 2013). Crusius et al. (1996) suggested that $5-40 \mu g \mathrm{~g}^{-1}$ Mo implies an

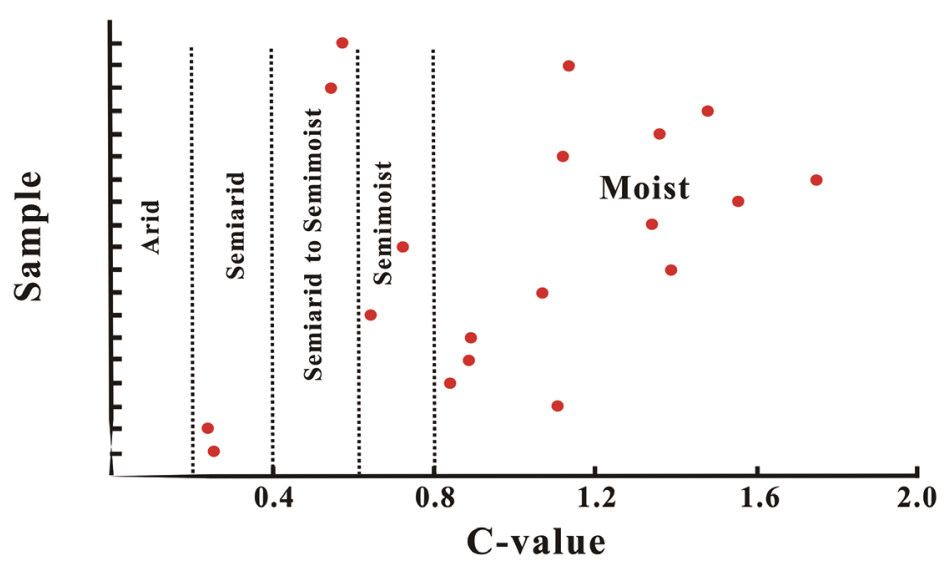

Fig. 6. The $\mathrm{C}$-value $[\Sigma(\mathrm{Fe}+\mathrm{Mn}+\mathrm{Cr}+\mathrm{Ni}+\mathrm{V}+\mathrm{Co}) / \Sigma(\mathrm{Ca}+\mathrm{Mg}+\mathrm{Sr}+\mathrm{Ba}+\mathrm{K}+\mathrm{Na})]$ of Zhanjin Formation samples, reflecting paleoclimate. The distinguishing criteria are after Cao et al. (2012). (Color online only) 
euxinic environment. The Mo contents in samples range from $0.48-1.58 \mu \mathrm{g} \mathrm{g}^{-1}$ (average $=0.95 \mu \mathrm{g} \mathrm{g}^{-1}$ ), showing no enrichment tendency, which indicates that the samples were deposited in an oxic environment.

Trace element ratios have also been widely used as palaeoredox proxies, such as $\mathrm{U} / \mathrm{Th}, \mathrm{V} / \mathrm{Cr}, \mathrm{V} / \mathrm{Sc}$, and $\mathrm{Ni} /$ Co (Lewan and Maynard 1982; Jones and Manning 1994; Wignall and Twitchett 1996; Kimura and Watanabe 2001). Commonly, Th is unaffected by redox conditions, whereas the $\mathrm{U}$ concentration will be enriched in sediments under reducing conditions and be depleted from deposits under oxidizing conditions. Wignall and Twitchett (1996) proposed that anoxic environments lead to $\mathrm{Th} / \mathrm{U}$ ratios that range from 0 - 2 in the sediments. In the Zhanjin Formation samples, the $\mathrm{Th} / \mathrm{U}$ ratios varied from $3.16-10.85$ with an average of 5.73, pointing out an oxic depositional environment (Fig. 2). Additionally, $\mathrm{V}$ is also a redox-sensitive element with concentrated tendency in deposits underlying anoxic or near-anoxic waters (Lewan and Maynard 1982). Jones and Manning (1994) indicated that the $\mathrm{V} / \mathrm{Cr}$ ratio $<2$ suggests an oxidation condition, while 2 - 4.25 implies suboxic conditions, and $>4.25$ represents anoxic to euxinic conditions. $\mathrm{V} / \mathrm{Cr}$ ratio values range between 1.30 and 2.33 in the Zhangjin Formation samples with an average of 1.89, suggesting that they were derived mainly from an oxic environment (Fig. 2). Moreover, Kimura and Watanabe (2001) suggested that a V/Sc value below 9 is a good sign of oxidizing conditions. The V/Sc ratios of the Zhanjin Formation sediments range from $1.76-10.98$ with an average of 8.38 , displaying an oxic water environment. Jones and Manning (1994) pointed out that $\mathrm{Ni} / \mathrm{Co}$ ratios below 5 reflected an oxic environment, whereas ratios above 5 suggested a suboxic or anoic environment. The Ni/Co ratios of the Zhanjin Formation sediments vary from $1.72-2.49$ with an average of 2.05. In the cross plots diagram (Fig. 7), Mo content, V/ $\mathrm{Cr}, \mathrm{Ni} / \mathrm{Co}$, and $\mathrm{V} /(\mathrm{V}+\mathrm{Ni})$ ratios were used as palaeoredox proxies for further determining the redox conditions. All of the samples in this study are plotted in the oxic zone.
In conclusion, all redox-sensitive trace element parameters are consistent in revealing that the Zhanjin Formation sediments were deposited beneath an oxic water column.

$\mathrm{Ce}$ anomalies $(\delta \mathrm{Ce})$ in rare earth element distribution patterns are widely accepted as an effective indicator for estimating the palaeoredox environment (Holser 1997; Shields and Stille 2001; Pálfy and Zajzon 2012). In general, $\delta \mathrm{Ce}$ values present enrichment in reducing conditions. As shown in Table 3 , the $\delta \mathrm{Ce}$ values of the samples range from $0.88-1.09$ with a mean of 0.97 , and the values of most of the samples are lower than 1 , showing a slightly depleted $\delta \mathrm{Ce}$ characteristic. These data may reflect a slightly oxic (or dysoxic) condition during sediment deposition, supporting the above result.

\subsection{Paleoproductivity Proxies}

$\mathrm{N}$ and $\mathrm{P}$ are the most important nutrient elements for plankton. Paleoproductivity in a marine environment is controlled mainly by the availability of $\mathrm{N}$ and $\mathrm{P}$ (Holland 1978; Luo et al. 2013; Zeng et al. 2015). P is regarded as the ultimate limiting factor in marine environments and a major constituent of skeletal material and plays a fundamental role in many metabolic processes (Tyrrell 1999; Tribovillard et al. 2006). Consequently, $\mathrm{P}$ content is widely used as an indicator for paleoproductivity. Organic matter and authigenic minerals may have a dilution effect on the absolute $\mathrm{P}$ content in terrigenous detrital matter. In order to mitigate this effect, $\mathrm{P} /$ $\mathrm{Ti}$ or $\mathrm{P} / \mathrm{Al}$ is used to evaluate the paleoproductivity, because $\mathrm{Ti}$ or $\mathrm{Al}$ generally originates from terrigenous detrital matter (Algeo and Maynard 2004; Pujol et al. 2006; Algeo et al. 2011). In this study, the $\mathrm{P} / \mathrm{Ti}$ ratios ranged from $0.04-0.12$ with an average of 0.07 (Table 2), close to those for PAAS (0.13) and far below that of the cherts (0.34) in the Ubara section. According to Algeo et al. (2011), the chert facies at Ubara section present moderate paleoproductivity during their deposition. Therefore, the samples in the present study were thought to be a characteristic of low paleoproductivity
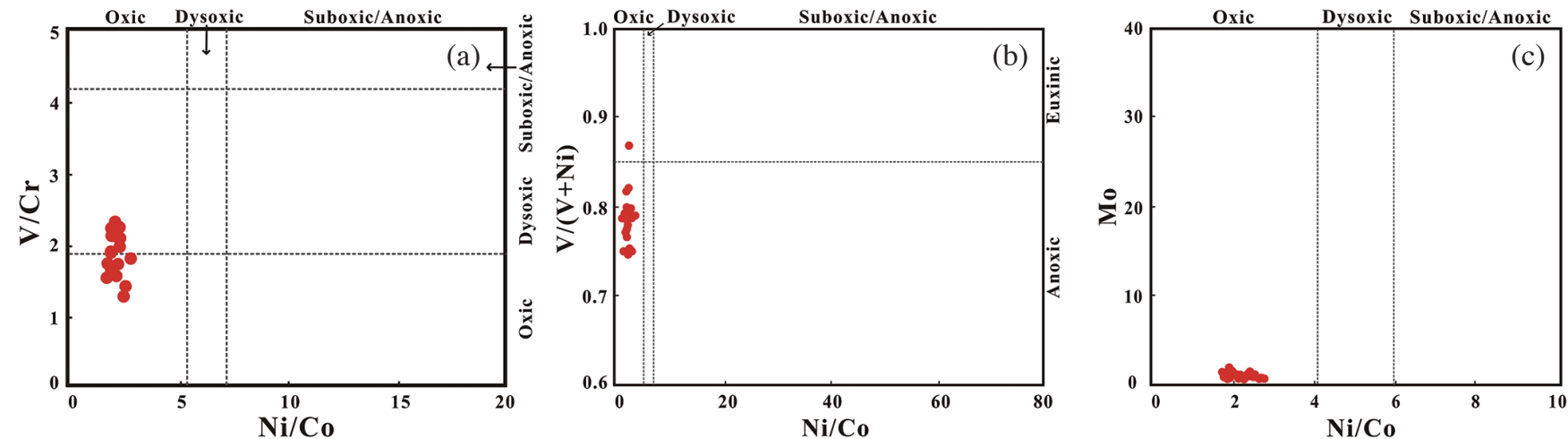

Fig. 7. Cross plots of trace element ratios used as paleoredox proxies. (a) $\mathrm{V} / \mathrm{Cr}$ vs. Ni/Co, (b) $\mathrm{V} /(\mathrm{V}+\mathrm{Ni}$ ) vs. Ni/Co, and (c) $\mathrm{Mo} v$ s. Ni/Co. Boundaries for different redox environments from Hatch and Leventhal (1992), Jones and Manning (1994), and Xu et al. (2012). (Color online only) 
during the Zhanjin Formation sedimentation.

The barite accumulation rate shows a positive correlation with primary productivity in the marine sediments (Dymond et al. 1992; Paytan et al. 1996; Paytan and Griffith 2007). Dean et al. (1997) suggested $\mathrm{Ba} / \mathrm{Ti}$ or $\mathrm{Ba} / \mathrm{Al}$ can be used to qualitatively assess the paleoproductivity. $\mathrm{Ti}$ or $\mathrm{Al}$ is also used as the proxy to eliminate the dilution effect of other components. Both ratios may represent the amount of organisms in the ancient sea. In the Zhanjin Formation sediments, $\mathrm{Ba} / \mathrm{Al}$ ratios vary from 6.4 - 102.6 with a mean of 20.5 (Table 2). Zeng et al. (2015) reported that the Changliang Mountain marine oil shale in the North Qiangtang Basin show moderate to high primary productivity, with the $\mathrm{Ba} / \mathrm{Al}$ ratios ranging from 49.2 - 124 and 85.6 - 212 (mean of 71.3 and 134, respectively). The $\mathrm{Ba} / \mathrm{Al}$ ratios in the Zhangjin Formation, by contrast, indicate relatively low paleoproductivity.

\subsection{Implication for Organic Matter Accumulation and Dilution}

The accumulation of organic matter in sediments demand a specific environment generally considered to be related to three main controlling factors, including (1) high primary productivity (input); (2) dysoxic to anoxic depositional environment (preservation); and (3) sedimentary rate (dilution of organic matter) (Canfield 1989; Pedersen and Calvert 1990; Tyson 2005; Bonis et al. 2010; Wei et al. 2012; Zeng et al. 2015; Fu et al. 2016).

As stated above, the Low Permian sediments in the Qiangtang Basin were deposited under humid climatic conditions. This condition is proper for living organisms (Fu et al. 2016), but within the studied interval, the samples present a relatively low paleoproductivity characteristic. In addition, several geochemical proxies indicate that the Zhanjin Formation sediments were deposited beneath a slightly oxic water column, which is unfavorable for organic matter preservation.

The $\omega(\mathrm{La})_{\mathrm{N}} / \omega(\mathrm{Yb})_{\mathrm{N}}$ ratio values (ratio of $\mathrm{La}$ and $\mathrm{Yb}$ normalized by the North American Shale Composite; Haskin et al. 1968) are usually used to indicate the mudstone sedimentary rate. If the sedimentary rate is fast, leading to weak rare earth element fractionation, and the $\omega(\mathrm{La})_{\mathrm{N}} / \omega(\mathrm{Yb})_{\mathrm{N}}$ value is close to 1 (Zeng et al. 2015; Fu et al. 2016), the average $\omega(\mathrm{La})_{\mathrm{N}} / \omega(\mathrm{Yb})_{\mathrm{N}}$ ratio value for the Zhanjin Formation sediments from the Qiangtang Basin is 0.87 , suggesting a fast sedimentary rate during deposition. The fast sedimentary rate would result in organic matter dilution.

\section{CONCLUSIONS}

The geochemical characteristics of Zhanjin Formation sediments from the Qiangtang Basin were investigated in this study. The samples generally show a developed mud flat characteristic with light richer clay content. Element contents, ratio values as well as discrimination diagrams were used to constrain the paleoredox environment. Those geochemical data proved that these sediments were deposited mainly beneath a slightly oxic water column with relatively low paleoproductivity as evidenced by the $\mathrm{P} / \mathrm{Ti}$ (mean of 0.07 ) and $\mathrm{Ba} /$ $\mathrm{Al}$ (mean of 20.5). Through geological analysis and comparison, the Jiaomuri area environment during Zhanjin Formation sediment deposition was unfavorable for organic matter preservation. On the other side, the palaeoclimate indexes such as the $\mathrm{C}$-value $(0.24-1.75)$ and $\mathrm{Sr} / \mathrm{Cu}(1.28$ - 11.58) reveal a humid climatic condition, which was suitable for living organisms. The $\omega(\mathrm{La})_{\mathrm{N}} / \omega(\mathrm{Yb})_{\mathrm{N}}$ ratio values indicate a fast sedimentary rate during the deposition period.

Acknowledgements This research was supported by the National Natural Science Foundation of China (No. 41576066, 41602125), China Postdoctoral Science Foundation (No. 2016M601085), and China Geological Survey (No. 121011221112). All authors express their deep gratitude to the Chengdu Center, China Geological Survey for providing all of the samples and offering selfless assistance during this research.

\section{REFERENCES}

Algeo, T. J. and J. B. Maynard, 2004: Trace-element behavior and redox facies in core shales of Upper Pennsylvanian Kansas-type cyclothems. Chem. Geol., 206, 289-318, doi: 10.1016/j.chemgeo.2003.12.009. [Link]

Algeo, T. J., K. Kuwahara, H. Sano, S. Bates, T. Lyons, E. Elswick, L. Hinnov, B. Ellwood, J. Moser, and J. B. Maynard, 2011: Spatial variation in sediment fluxes, redox conditions, and productivity in the PermianTriassic Panthalassic Ocean. Palaeogeogr. Palaeoclimatol. Palaeoecol., 308, 65-83, doi: 10.1016/j.palaeo.2010.07.007. [Link]

Bonis, N. R., M. Ruhl, and W. M. Kürschner, 2010: Climate change driven black shale deposition during the endTriassic in the western Tethys. Palaeogeogr. Palaeoclimatol. Palaeoecol., 290, 151-159, doi: 10.1016/j. palaeo.2009.06.016. [Link]

Brumsack, H. J., 1989: Geochemistry of recent TOC-rich sediments from the Gulf of California and the Black Sea. Geol. Rundsch., 78, 851-882, doi: 10.1007/ BF01829327. [Link]

Canfield, D. E., 1989: Reactive iron in marine sediments. Geochim. Cosmochim. Acta, 53, 619-632, doi: 10.1016/0016-7037(89)90005-7. [Link]

Cao, J., M. Wu, Y. Chen, K. Hu, L. Bian, L. Wang, and Y. Zhang, 2012: Trace and rare earth element geochemistry of Jurassic mudstones in the northern Qaidam Basin, northwest China. Chemie der Erde, 72, 245-252, doi: 10.1016/j.chemer.2011.12.002. [Link] 
Cao, J., C. Song, X. Fu, M. Chen, B. Zheng, and W. Sun, 2015: Basic characteristics of Permian Zhanjin source rock in Well Qiangzi-5 in Qiangtang Basin. Mar. Origin Petrol. Geol., 20, 15-20, doi: 10.3969/j.issn.16729854.2015.02.003. (in Chinese) [Link]

Crusius, J., S. Calvert, T. Pedersen, and D. Sage, 1996: Rhenium and molybdenum enrichments in sediments as indicators of oxic, suboxic and sulfidic conditions of deposition. Earth Planet. Sci. Lett., 145, 65-78, doi: 10.1016/S0012-821X(96)00204-X. [Link]

Dean, W.E., J. V. Gardner, and D. Z. Piper, 1997: Inorganic geochemical indicators of glacial-interglacial changes in productivity and anoxia on the California continental margin. Geochim. Cosmochim. Acta, 61, 4507-4518, doi: 10.1016/S0016-7037(97)00237-8. [Link]

Ding, W., H. Wan, Y. Zhang, and G. Han, 2013: Characteristics of the Middle Jurassic marine source rocks and prediction of favorable source rock kitchens in the Qiangtang Basin of Tibet. J. Asian Earth Sci., 66, 6372, doi: 10.1016/j.jseaes.2012.12.025. [Link]

Dymond, J., E. Suess, and M. Lyle, 1992: Barium in deep-sea sediment: A geochemical proxy for paleoproductivity. Paleoceanography, 7, 163-181, doi: 10.1029/92PA00181. [Link]

Feng, X. L., X. G. Fu, F. W. Tan, and W. B. Chen, 2010: Geochemical characteristics and tectonic significance of upper Triassic Tumengela Formation in Woruo Mountains, North Qiangtang Basin. Geoscience, 24, 910-918. (in Chinese)

Fu, X., J. Wang, F. Tan, X. Feng, D. Wang, and J. He, 2013: Gas hydrate formation and accumulation potential in the Qiangtang Basin, northern Tibet, China. Energ. Convers. Manage., 73, 186-194, doi: 10.1016/j.enconman.2013.04.020. [Link]

Fu, X., J. Wang, W. Chen, X. Feng, D. Wang, C. Song, and S. Zeng, 2016: Elemental geochemistry of the early Jurassic black shales in the Qiangtang Basin, eastern Tethys: constraints for palaeoenvironment conditions. Geol. J., 51, 443-454, doi: 10.1002/gj.2642. [Link]

Guo, Z., Y. Li, Z. Nan, and H. Ye, 2008: Relationship between deformation structure and petroleum accumulation and preservation, Qiangtang Basin, Tibet. Petrol. Explor. Develop., 35, 563-568, doi: 10.1016/S18763804(09)60089-6. [Link]

Haskin, L. A., T. R. Wildeman, and M. A. Haskin, 1968: An accurate procedure for the determination of the rare earths by neutron activation. J. Radioanal. Chem., 1, 337-348, doi: 10.1007/BF02513689. [Link]

Hatch, J. R. and J. S. Leventhal, 1992: Relationship between inferred redox potential of the depositional environment and geochemistry of the Upper Pennsylvanian (Missourian) Stark Shale Member of the Dennis Limestone, Wabaunsee County, Kansas, U.S.A. Chem . Geol., 99, 65-82, doi: 10.1016/0009-2541(92)90031-
Y. [Link]

He, J., J. Wang, X. Fu, C. Zheng, and Y. Chen, 2012: Assessing the conditions favorable for the occurrence of gas hydrate in the Tuonamu area Qiangtang basin, Qinghai-Tibetan, China. Energ. Convers. Manage., 53, 11-18, doi: 10.1016/j.enconman.2011.08.012. [Link]

Holland, H. D., 1978: The Chemistry of the Atmosphere and Oceans, New York: Wiley-Interscience, $351 \mathrm{pp}$.

Holser, W. T., 1997: Evaluation of the application of rareearth elements to paleoceanography. Palaeogeogr. $\mathrm{Pa}$ laeoclimatol. Palaeoecol., 132, 309-323, doi: 10.1016/ S0031-0182(97)00069-2. [Link]

Hu, J., Q. Li, N. Fang, J. Yang, and D. Ge, 2015: Geochemistry characteristics of the Low Permian sedimentary rocks from central uplift zone, Qiangtang Basin, Tibet: Insights into source-area weathering, provenance, recycling, and tectonic setting. Arab.J. Geosci., 8, 53735388, doi: 10.1007/s12517-014-1583-8. [Link]

Hunt, J. M., 1979: Petroleum Geochemistry and Geology, Oxford: Freeman, New York, 617 pp.

Jia, J., Z. Liu, A. Bechtel, S. A. I. Strobl, and P. Sun, 2013: Tectonic and climate control of oil shale deposition in the Upper Cretaceous Qingshankou Formation (Songliao Basin, NE China). Int. J. Earth Sci., 102, 1717-1734, doi: 10.1007/s00531-013-0903-7. [Link]

Jin, X., 2002: Permo-Carboniferous sequences of Gondwana affinity in southwest China and their paleogeographic implications. J. Asian Earth Sci., 20, 633-646, doi: 10.1016/S1367-9120(01)00084-0. [Link]

Jones, B. and D. A. C. Manning, 1994: Comparison of geochemical indices used for the interpretation of palaeoredox conditions in ancient mudstones. Chem. Geol., 111, 111-129, doi: 10.1016/0009-2541(94)90085-X. [Link]

Kimura, H. and Y. Watanabe, 2001: Oceanic anoxia at the Precambrian-Cambrian boundary. Geology, 29, 995998, doi: 10.1130/0091-7613(2001)029<0995:OAATPC $>2.0 . C O ; 2$. [Link]

Lerman, A., 1978: Lakes: Chemistry, Geology, Physics, Springer New York, doi: 10.1007/978-1-4757-1152-3. [Link]

Lewan, M. D. and J. B. Maynard, 1982: Factors controlling enrichment of vanadium and nickel in the bitumen of organic sedimentary rocks. Geochim. Cosmochim. Acta, 46, 2547-2560, doi: 10.1016/0016-7037(82)90377-5. [Link]

Li, C., Q. Zhai, Y. Dong, Q. Zeng, and X. Huang, 2007: Longmu Co-Shuanghu plate suture in the Qinghai-Tibet Plateau and records of the evolution of the PaleoTethyan Ocean in the Qiangtang area, Tibet, China. Geol. Bull. China, 26, 13-21, in Chinese with English abstract.

Luo, Q., N. Zhong, L. Zhu, Y. Wang, J. Qin, L. Qi, Y. Zhang, and Y. Ma, 2013: Correlation of burial organic carbon and paleoproductivity in the Mesoproterozoic 
Hongshuizhuang Formation, northern North China. Chin. Sci. Bull., 58, 1299-1309, doi: 10.1007/s11434012-5534-z. [Link]

Meng, Q., Z. Liu, A. A. Bruch, R. Liu, and F. Hu, 2012: Palaeoclimatic evolution during Eocene and its influence on oil shale mineralisation, Fushun basin, China. J. Asian Earth Sci., 45, 95-105, doi: 10.1016/j.jseaes.2011.09.021. [Link]

Nesbitt, H. W. and G. M. Young, 1982: Early Proterozoic climates and plate motions inferred from major element chemistry of lutites. Nature, 299, 715-717, doi: 10.1038/299715a0. [Link]

Pálfy, J. and N. Zajzon, 2012: Environmental changes across the Triassic-Jurassic boundary and coeval volcanism inferred from elemental geochemistry and mineralogy in the Kendlbachgraben section (Northern Calcareous Alps, Austria). Earth Planet. Sci. Lett., 335-336, 121134, doi: 10.1016/j.eps1.2012.01.039. [Link]

Paytan, A. and E. M. Griffith, 2007: Marine barite: Recorder of variations in ocean export productivity. Deep-Sea Res. Part II-Top. Stud. Oceanogr., 54, 687-705, doi: 10.1016/j.dsr2.2007.01.007. [Link]

Paytan, A., M. Kastner, and F. P. Chavez, 1996: Glacial to interglacial fluctuations in productivity in the equatorial Pacific as indicated by marine barite. Science, 274, 1355-1357, doi: 10.1126/science.274.5291.1355. [Link]

Pedersen, T. F. and S. E. Calvert, 1990: Anoxia vs. productivity: What controls the formation of organic-carbonrich sediments and sedimentary rocks? AAPG Bull., 74, 454-466.

Plank, T. and C. H. Langmuir, 1998: The chemical composition of subducting sediment and its consequences for the crust and mantle. Chem. Geol., 145, 325-394, doi: 10.1016/S0009-2541(97)00150-2. [Link]

Pujol, F., Z. Berner, and D. Stüben, 2006: Palaeoenvironmental changes at the Frasnian/Famennian boundary in key European sections: Chemostratigraphic constraints. Palaeogeogr. Palaeoclimatol. Palaeoecol., 240, 120145, doi: 10.1016/j.palaeo.2006.03.055. [Link]

Ross, D. J. K. and R. M. Bustin, 2009: Investigating the use of sedimentary geochemical proxies for paleoenvironment interpretation of thermally mature organic-rich strata: Examples from the Devonian-Mississippian shales, Western Canadian Sedimentary Basin. Chem. Geol., 260, 1-19, doi: 10.1016/j.chemgeo.2008.10.027. [Link]

Shields, G. and P. Stille, 2001: Diagenetic constraints on the use of cerium anomalies as palaeoseawater redox proxies: An isotopic and REE study of Cambrian phosphorites. Chem. Geol., 175, 29-48, doi: 10.1016/S00092541(00)00362-4. [Link]

Song, C., J. Wang, X. Fu, X. Feng, S. Zeng, and L. He, 2013a: Geochemical characteristics and signatures of the sandstones from Zangxiahe Formation in Qiangtang Basin. Earth Sci. J. China Univ. Geosci., 38, 508518. (in Chinese)

Song, C., J. Wang, X. Fu, and L. He, 2013b: Mesozoic and Cenozoic cooling history of the Qiangtang block, northern Tibet, China: New constraints from apatite and zircon fission track data. Terr. Atmos. Ocean. Sci., 24, 985-998, doi: 10.3319/TAO.2013.07.05.02(TT). [Link]

Song, C., J. Cao, J. Wang, F. Tan, X. Fu, J. He, S. Zeng, and L. He, 2014: The discovery and basic characteristics of ancient reservoir in Permian of Jiaomuchaka Area, Qiangtang Basin. Xinjiang Geology, 32, 87-91. (in Chinese)

Taylor, S. R. and S. M. McClennan, 1985: The Continental Crust: Its Composition and Evolution, Blackwell Scientific Publications, Oxford, 312 pp.

Tenger, W. Liu, Y. Xu, J. Chen, K. Hu, and C. Gao, 2006: Comprehensive geochemical identification of highly evolved marine hydrocarbon source rocks: Organic matter, paleoenvironment and development of effective hydrocarbon source rocks. Chin. J. Geochem., 25, 333-340, doi: 10.1007/s11631-006-0332-4. [Link]

Tribovillard, N., T. J. Algeo, T. Lyons, and A. Riboulleau, 2006: Trace metals as paleoredox and paleoproductivity proxies: An update. Chem. Geol., 232, 12-32, doi: 10.1016/j.chemgeo.2006.02.012. [Link]

Tyrrell, T., 1999: The relative influences of nitrogen and phosphorus on oceanic primary production. Nature, 400, 525-531, doi: 10.1038/22941. [Link]

Tyson, R. V., 2005: The "productivity versus preservation" controversy: Cause, flaws, and resolution. In: Harris, N. B. (Ed.), The Deposition of Organic-carbon-rich Sediments: Models, Mechanisms, and Consequences, SEPM Special Publication, No. 82, SEPM (Society for Sedimentary Geology), Tulsa, 17-33.

Wang, J., X. Fu, W. Chen, and Z. Wang, 2007: The Late Triassic Paleo-weathering crust in the Qiangtang Basin, Northern Tibet: Geology, geochemistry and significance. Acta Sedimentologica Sinica, 25, 487-494. (in Chinese)

Wang, Z., X. Fu, X. Feng, C. Song, D. Wang, W. Chen, and S. Zeng, 2017: Geochemical features of the black shales from the Wuyu Basin, southern Tibet: Implications for palaeoenvironment and palaeoclimate. Geol. J., 52, 282-297, doi: 10.1002/gj.2756. [Link]

Wedepohl, K. H., 1978: Manganese: Abundance in common sediments and sedimentary rocks. Handbook of Geochemistry, Springer-Verlag Berlin Heidelberg, $442 \mathrm{pp}$.

Wedepohl, K. H., 1991: The composition of the upper Earth's crust and the natural cycles of selected metals. Metals in the natural raw materials. Natural Resources. In: Merian, E. (Ed.), Metals and Their Compounds in 
the Environment, VCH, Weinheim, Germany, 3-17.

Wei, G., Y. Liu, X. Li, L. Shao, and D. Fang, 2004: Major and trace element variations of the sediments at ODP Site 1144, South China Sea, during the last $230 \mathrm{ka}$ and their paleoclimate implications. Palaeogeogr. Palaeoclimatol. Palaeoecol., 212, 331-342, doi: 10.1016/j. palaeo.2004.06.011. [Link]

Wei, H., D. Chen, J. Wang, H. Yu, and M. E. Tucker, 2012: Organic accumulation in the lower Chihsia Formation (Middle Permian) of South China: Constraints from pyrite morphology and multiple geochemical proxies. Palaeogeogr. Palaeoclimatol. Palaeoecol., 353-355, 73-86, doi: 10.1016/j.palaeo.2012.07.005. [Link]

Wignall, P. B. and R. J. Twitchett, 1996: Oceanic anoxia and the end Permian mass extinction. Science, 272, 11551158, doi: 10.1126/science.272.5265.1155. [Link]

Xu, L., B. Lehmann, J. Mao, T. F. Nägler, N. Neubert, M. E. Böttcher, and P. Escher, 2012: Mo isotope and trace element patterns of Lower Cambrian black shales in South China: Multi-proxy constraints on the paleoenvironment. Chem. Geol., 318-319, 45-59, doi: 10.1016/j. chemgeo.2012.05.016. [Link]

Yarincik, K. M., R. W. Murray, T. W. Lyons, L. C. Peter- son, and G. H. Haug, 2000: Oxygenation history of bottom waters in the Cariaco Basin, Venezuela, over the past 578,000 years: Results from redox-sensitive metals (Mo, V, Mn, and Fe). Paleoceanography, 15, 593-604, doi: 10.1029/1999PA000401. [Link]

Zeng, S., J. Wang, X. Fu, W. Chen, X. Feng, D. Wang, C. Song, and Z. Wang, 2015: Geochemical characteristics, redox conditions, and organic matter accumulation of marine oil shale from the Changliang Mountain area, northern Tibet, China. Mar. Petrol. Geol., 64, 203-221, doi: 10.1016/j.marpetgeo.2015.02.031. [Link]

Zhai, Q., C. Li, L. Cheng, and Y. Zhang, 2004: Geological features of Permian ophiolite in the Jiaomuri area, Qiangtang, Tibet, and its tectonic significance. Geological Bulletin of China, 23, 1228-1230. (in Chinese)

Zhang, Y., G. R. Shi, and S. Shen, 2013: A review of Permian stratigraphy, palaeobiogeography and palaeogeography of the Qinghai-Tibet Plateau. Gondwana Res., 24, 55-76, doi: 10.1016/j.gr.2012.06.010. [Link]

Zhao, Z., J. Zhao, H. Wang, J. Liao, and C. Liu, 2007: Distribution characteristics and applications of trace elements in Junggar Basin. Nat. Gas Explor. Dev., 30, 30-33. (in Chinese) 